\title{
Thoughts on the Quality Cultivation of Students Majoring in Hotel Management in Higher Vocational Colleges*
}

\author{
Yifeng Bai \\ Yunnan College of Tourism Vocation \\ Kunming, China
}

\begin{abstract}
The development of modern hotel industry puts forward higher requirements for the quality of employees. In cultivating hotel management professionals, higher vocational colleges need to master the training of the comprehensive quality of students, analyze the problems existing in the current personnel training work, take the all-round development of people as the guiding ideology, and establish a student-based education service model to give full play to the exemplary role of teachers, follow the correct steps and methods of talent training, and adopt multiple scientific evaluation methods to strengthen the integration of students 'professional and cultural qualities.
\end{abstract}

Keywords—tourism; higher vocational; quality

\section{INTRODUCTION}

As an important part of the tourism reception, the reception capacity and service level of hotel industry are closely related to the development of the tourism industry. The hotel industry puts forward higher requirements for the quality of the employees. Higher vocational hotel management is an important position to train first-line employees in service hotels. It plays a pivotal role in meeting industry needs, promoting local industry development, and cultivating students to adapt to job requirements faster and better. However, in reality, there is still a certain gap between the hotel professionals trained by higher vocational colleges and the actual needs of hotels. Although graduates of higher vocational hotel management majors maintain a high employment rate, the employment rate in the industry is low. In particular, there has been a decrease in the number of students who remain in the hotel industry. Higher vocational education is a bridge connecting students and professions. Only by meeting the needs of the two sides can it build a smooth channel for student employment development. Therefore, it is necessary to think deeply about the cultivation and orientation of the quality of higher vocational hotel management students from the two aspects of hotel demand and student demand, and to pay attention to the professional quality of students to meet the needs of the hotel industry. It is also necessary to fully consider various development needs of students, integrate cultural quality

*Fund Project: The phased results of the Yunnan Provincial Department of Education Science Research Fund Project (2018JS625). education of students and professional quality training together, and promote all-round development of students.

\section{CURRENT Status of Hotel Management STUDENTS IN HighER VocATIONAL COLLEGES}

\section{A. Paying Special Attention to the Cultivation of Students' Professional Quality}

From the perspective of the orientation of higher vocational hotel management personnel training, whether it is from the characteristics of vocational education or the actual situation of hotel management, the school pays more attention to the cultivation of students' professional knowledge and skills, and requires students to have solid professional basic knowledge and basic theory, master strong practical operation skills, familiar with modern star hotel management methods and means. From the perspective of curriculum design, the courses are basically divided into basic courses and professional courses. Public courses do not differ greatly among different majors, and professional courses basically cover the knowledge points and skills involved in hotel management. Professional courses and professional cognitive education, hotel cognitive internship, the top job internship accounted for a large proportion, and vocational characteristics of vocational education are more obvious. In addition, in the degree of emphasis on the curriculum, neither the school teachers nor the students pay attention to the basic courses. They have not yet clearly recognized the important role of the basic courses in the personal development and career advancement of the students, and the combination of the basic courses and the professional courses is not close enough. In other words, the current curriculum and training programs reflect that the school attaches great importance to the cultivation of students' professional quality, but does not comprehensively improve the students' cultural quality and professional quality from the perspective of students' long-term development.

\section{B. The Timeliness and Effectiveness of Student Learning Must Be Improved}

Most students of higher vocational hotel management have established a correct understanding of hotel service 
work and mastered the relevant knowledge and skills of hotel service to a certain extent. However, judging from the possibility of students working in the hotel industry in the future, most students have an uncertain attitude about whether they will continue to work in hotels, and in particular, they must combine the actual situation of income and personal development. However, the long-term problems of low threshold, low income, and high departure rate of hotel service personnel are not only related to the overall level of employees, but also related to the development of the hotel industry and the level of social awareness of the hotel service industry. In order to improve the quality of service and reducing the rate of staff turnover, it needs the joint efforts of hotel, school and society. Combining with the current employment reality, higher vocational colleges should not only strengthen the education of hotel professional knowledge and skills, but also consider the long-term development of students, strengthen the education of students' ideological and moral, cultural and artistic, social interaction and other aspects, and simultaneously improve cultural quality of students. Only with better cultural quality and professional quality, students can have strong competitiveness in future employment, and higher vocational colleges can also develop healthy and effective development by cultivating high-quality hotel service comprehensive talents.

\section{There Is Still Room for Improvement Between Talent Training and Employment in Higher Vocational Colleges}

Among the candidates at different levels and in different majors of the hotel, the higher vocational graduates of the hotel management specialty not only have the common problems that exist after the 90th century, but also have the shortcomings as graduates of higher vocational hotel management majors. It shows that there is still room for improvement in personnel training and actual employment in higher vocational colleges. The graduates of the hotel management majors in the higher vocational colleges are mostly in the antechamber, guest rooms, catering and other first-line customer service departments, mainly engaged in service reception work in hotel. In the selection and employment of personnel, because the students of higher vocational hotel management have the advantages of hotel specialty, school-enterprise cooperation background, graduates are more malleable than social recruitment, and they are mount guard quickly, so the front-line customer service departments of hotels tend to recruit graduates directly from schools. In terms of personnel training and teaching, the hotel hopes that the school can handle the relationship between teaching and internship, pay attention to internship and social practice, cultivate students' application ability, strengthen the education of professional knowledge, master solid hotel expertise, and reduce the number of entirely ignorant or the appearance of " just a little impression" in the work; strengthen the education of cultural quality, broaden the knowledge of students, help students master basic knowledge and basic life skills; establish a correct outlook on life and values, and cultivate good moral sentiments and labor attitudes; strengthen the cultivation of students' interpersonal communication and organizational coordination skills, and improve the sense of competition and innovation of students.

\section{The Depth of School-enterprise Cooperation Must Be Further Broadened and Deepened}

The depth and breadth and effectiveness of the current school-enterprise professional school-enterprise cooperation must be further broadened and deepened. Hoteliers hope that the school can provide qualified graduates for them, and the school also hopes that the hotel can give full play to the characteristics of the industry to help the cause of education. However, in the environment of school-enterprise cooperation to train students, the roles of both enterprises and schools are too simple and rough to define. As a profitable company, the hotel needs to comprehensively consider the cost of manpower, material resources, and money spent by students on internships. Therefore, students may encounter differences between interns and regular employees in hotel internships, lack of systematic preemployment training, and incomplete internship management systems. In addition, the involvement of hotel teachers in school education is not enough. The cooperation between schools and hotels in jointly training teachers and developing courses is not yet in-depth enough, and there is a lack of regular discussion and exchange, the theory and practice, school teaching and hotel teaching in the course teaching have not been fully integrated, and the training of hotel management professionals does not reflect the cooperative education, win-win cooperation and cooperative development.

\section{THE GUIDING IDEOLOGY AND PRINCIPLES OF STUDENT QUALITY TRAINING}

\section{A. Guiding Ideology}

The Marxist theory of the all-round development of human beings is the guiding ideology and theoretical basis for the formulation of educational purposes in China, and it is also one of the theoretical foundations of the ideology and practice of quality education. In the report of the 19th National Congress of the Communist Party of China, Xi Jinping pointed out that "social development and social progress centered on the all-round development of people are the ultimate goal of economic development", expounding the unity of all-round development of people and the overall development and progress of society [1]. For higher vocational colleges, improving the quality of personnel training and promoting the all-round development of students is organic unity. Without the correct direction of the overall development of human beings, it is impossible to improve the quality of personnel training effectively, and it is also difficult to guarantee the healthy development of higher vocational education. Therefore, under the guidance of Marxist theory on the all-round development of human beings, vocational colleges should aim at training modern hotel professionals with good professional quality and higher cultural quality, refine personnel training programs, grasp the 
quality of personnel training, and carry out overall education work.

\section{B. Principles}

In order to promote the all-round development of students and improve the comprehensive quality of hotel management students, higher vocational colleges should pay attention to the cultivation of students' cultural quality and professional quality in the process of talent training. They should be organically integrated into the whole process of education through educational activities such as campus sports projects, curriculum teaching, practice and training. In the implementation, it is necessary to pay attention to the following four points: First, the student is the center. Students are the starting point and end point of educational activities. Therefore, when conducting vocational quality education and cultural quality education for students, the school should fully consider the characteristics of higher vocational students and the specific requirements of the hotel management profession, combine students' demands, take students as the starting point, ensure that the teaching content and teaching process are what students want, what they need, and what they like, so as to better meet the needs of students 'comprehensive development; Secondly, teachers should play an exemplary role. Teachers' dedicated working attitude, rigorous academic style, sincere and modest way of dealing with people, broad knowledge, resourceful and resolute ability to deal with problems, and indomitable spirit in the face of difficulties are all examples of students' learning. Students consciously learn from teachers in the process of listening and watching, inspire students to actively pursue development and progress, under the driving force of internal motivation to encourage students to actively participate in learning life; third, follow the correct steps and methods of talent development. The professional quality and cultural quality are closely related. The cultural quality provides the basic conditions for the cultivation of professional quality, and the improvement of professional quality can promote the improvement of cultural quality. Therefore, when cultivating professional management talents in higher vocational schools, it is necessary to grasp the organic links between the courses, adopt an education method suitable for the level of higher vocational students, and enable students to master solid basic knowledge through basic cultural courses to promote the effective knowledge and skills of the hotel. At the same time, in the professional courses, pay attention to expanding knowledge points, echoing with basic cultural courses, and cultivating the comprehensive quality of students; fourth, the assessment methods are diversified and scientific. There are some differences between higher vocational education and university subject education in the orientation of personnel training, and students' development level and ability cannot be accurately judged by a simple course or a single achievement. Therefore, according to the curriculum characteristics of vocational education and the different focus of students 'ability training, it is necessary to adopt a combination of theory and practice to comprehensively examine ability of students.

\section{SUGGESTIONS ON THE INTEGRATION OF STUDENTS CULTURAL QUALITY AND PROFESSIONAL QUALITY}

First, cultural quality education runs through professional education. In order to improve the quality of personnel training and improve students' cultural quality and professional ability, professional teachers need to fully explore the humanistic spirit and cultural quality connotation contained in professional courses when teaching professional courses, and carry out cultural quality education through professional education. Through the process of teaching professional courses, the relevant content of cultural quality is penetrated, so that students can improve their own cultural quality while receiving professional knowledge and skills education. At the same time, through flexible and diverse ways such as online courses and on-site lectures, the use of elective courses has been effectively strengthened in the education of students in terms of cultural quality, give full play to the enthusiasm of students' independent learning, and combine students' interest in learning, so as to help them broaden their horizons and master more knowledge and skills.

Second, establish a student-oriented education service model. Students are the starting point and destination of school education. Vocational education should not only strengthen the training of students 'vocational skills, provide them with the knowledge and skills training they need for future employment, but also give full consideration to students as subjects with personal consciousness and initiative. Talent training not only needs to meet the requirements of the tourism industry for service talents, but also needs to meet the needs of students 'personal development. On the basis of student-centered, enhance the service awareness of higher vocational colleges, listen to the opinions and suggestions of students, and formulate more scientific and effective quality management strategies in terms of daily teaching, campus life, and practice. Establish a student-oriented education service model to improve the overall cultural quality of students.

Thirdly, innovate the teaching method of cultural quality course. The traditional cultural quality curriculum mainly focuses on classroom teaching, which is rather monotonous compared with the specialized curriculum with more handson operation, and the students' lack of understanding of the importance of cultural curriculum makes their interest in learning and learning effect unsatisfactory. Therefore, in the teaching of cultural quality curriculum, teachers should fully understand the textbooks and improve their individual abilities, professional level and teaching ability, draw on and learn from domestic and foreign teaching methods and methods that have better results, and break through traditional teaching methods, so as to stimulate students' interest in learning, and then promote the mastery of professional knowledge and skills, to provide the necessary basis and guarantee for students' future employment.

Fourth, build a high-level teaching team and promote the development of higher education institutions. Teachers play an important role in students' growth. They should not only impart cultural knowledge, but also help students to establish 
correct attitudes and attitudes and develop good habits. They should also influence and cultivate students with their own good personal qualities and words and deeds in daily teaching management. In the process of integrating the cultural quality and professional quality of the students, the teachers must consciously break through the boundaries between the professional courses and the cultural quality courses in the teaching process. Improving teaching level, and at the same time, they should enhance their personal cultural quality and professional knowledge according to the nature of the courses.

Fifth, enrich the campus cultural activities and promote the all-round development of students. Campus cultural activities play an important role in cultivating students' sentiment. By creating a good campus culture environment and organizing rich and colorful campus cultural activities, it is conducive to the formation of a progressive and harmonious cultural atmosphere. Give play to the leading role of the student associations and the leadership of the student management department, so that campus activities can be carried out in an effective and orderly manner, and Chinese and English speech contests, cultural knowledge contests, debates, etc. can be held to improve students' language application and expression skills, and invite experts to give special lectures and book-sharing meetings to expand students' knowledge, develop volunteer service to improve students' interpersonal communication ability, carry out psychological activities month series activities to help students grow up physically and mentally healthily, and hold vocational education activities to promote the glory of labor and valuable skills, create a great fashion of the times, and form a good atmosphere of "advocating a skill, not just academic ability".

\section{CONCLUSION}

Vocational personnel training is a systematic project that requires schools, teachers, and enterprises to participate in the education process. It is suggested to start from the vocational characteristics, establish a student-oriented educational service model, combine students' learning and development demands, and pay attention to their integration of cultural and professional qualities. Integrating with professional quality, through the effective integration inside and outside the classroom, inside and outside the school, inside and outside the specialty, giving play to the leading role of teachers in talent training, and continuously improving the quality of teaching. At the same time, schools can give play to the synergy between campus education and activity education, carry out colorful campus cultural activities, and effectively help students simultaneously improve their cultural knowledge and professional and technical abilities, and then with good professional quality and cultural quality to improve employability, promote the healthy and sustainable development of vocational education and hotel industry

\section{REFERENCES}

[1] Yang Min. Analysis of Xi Jinping's All-round Development Thoughts [J]. Scientific Socialism, 2018 (02): 92-96. (in Chinese)

[2] Bai Yuifeng. Research on Quality Culture Construction in Higher Vocational Colleges - Taking Yunnan Tourism Vocational College as an Example[J].Economist, 2018(03):210-212. (in Chinese). 